\title{
Microteaching Lesson Study of Biology Prospective Teacher to Develop Lesson Plan Design and Teaching Ability
}

\author{
M. Lukitasari ${ }^{1 *}$, R. Hasan ${ }^{2}$, W. Murtafiah ${ }^{3}$ \\ 1,3 Pendidikan Biologi, Universitas PGRI Madiun, Madiun, Indonesia \\ ${ }^{2}$ Pendidikan Biologi, Universitas Muhammadyah Bengkulu, Bengkulu, Indonesia \\ *e-mail: marheny@unipma.ac.id
}

\begin{abstract}
This research aimed to develop the learning tools of the biological subject in high school and the teaching biology ability of the teacher candidates through microteaching-lesson study (MLS). The combination of MLS activities was unfolded in preparing the real learning conditions for prospective teachers who will conduct the field practice in the actual classroom. Data were collected through the observation sheets, interviews, and microteaching scores that represented the students' teaching ability. The data were analyzed descriptively. The results showed that each student capable of designing three learning plans with good and excellent categories. The teaching ability and classroom management of students increase by the three activities that conducted, as can be seen from the mean of first $(55,77)$, the second $(71,88)$, and the third $(84,38)$ practice values. However, the students experienced difficulties in the stages of preparation and implementation concerning the more time needed as well as the more cycle activities. Therefore, the students argued that by the only three cycles of activities they experienced, then the LS would be constrained to introduce in the field practice program at school. The more cycles of MLS and guidance from the lecturer is still needed to make prospective teacher ready to implement LS in their field practice at school.
\end{abstract}

Keywords: Microteaching-Lesson Study, Lesson Plan, Teaching Ability

\section{Introduction}

Microteaching is a training technique of the course for pre-service teachers that is essential for the students who require to carry out the real teaching activities into the micro classroom along with their groups. The concept of training for prospective teachers is very appropriate with the focus and particular purpose of lesson study (LS). LS developed from Japanese jugyokenkyu, which derived from the word jugyo means learning, and kenkyu means to study or observation, is a form of activity to improve the ability and professionalism of teacher. It has been widely reported that LS implementation effectively improved teacher quality and students learning process as well as leading the collaboration and caring among students in the learning process (Chukwunyere et al., 2017; Doig \& Groves, 2011; Hasan et al., 2019; Hj Iksan et al., 2014; Ledger \& Fischetti, 2020; Murata, 2011; Myers, 2012). The modification of LS conducted by teachers also contributes significantly to the learning activities they do in the classroom. It showed that LS plays a significant role in collaborating and aligning the learning plans that teachers had developed through discussions when the plan was implemented (Damalie, 2018; Hj Iksan et al., 2014; Marble, 2007).

The existence of collaboration in the form of a discussion between friends becomes one of the keys to the development of self-ability (Gellert, 2008). Microteaching has the main purpose of preparing students to implement the field practice (PPL) by teaching directly at partner schools. Microteaching was an effective way to help students prepare optimally before implementing PPL or teaching practice in schools (Remesh, 2013; Suryani, 2014). Problems that arise and often complained is that students in preparing the components in the lesson plans have not been optimal, the lack of confidence they have, as well as the class management techniques that have not been perfect (Ghanaguru et al., 2013; Okobia et al., 2013).

\footnotetext{
${ }^{*}$ Corresponding author.

Received December 27, 2019; Accepted April 18, 2021; Available online September 25, 2021

Copyright @ 2021 by Author. Published by Universitas Pendidikan Ganesha.
}

Jurnal Pendidikan Indonesia (JPI) | 590 
The implementation of microteaching conducted by educational students is usually based on the initial context at the school when they came. The teachers at the school convey information about learning activities carried out at school. Learning plan is often rigid and do not accommodate the interests of learners in learning because it is created base on the academic indicators of material attainment such as those in the curriculum (Yang, 2017). Though as prospective teachers, educational students are demanded to possess a mature skill in planning and managing of the class (Handayani, 2018; Nugraheni, 2019; Saun, 2015). The problems that students faced related to the implementation of microteaching need to be overcome by improving student abilities during the lecture activity. The use of the lesson study model combined with microteaching can be a solution in overcoming the problems that might come and must be faced by these prospective teacher students.

The development of teacher candidate students' abilities through microteaching can be improved through the application of lesson study in a period. The combination of microteaching-lesson study (MLS) implementation will strengthen the students' sensitivity, especially in preparing the PPL to plunge teaching in school. Previous study who developed the model in her microteaching activities showed that in the planning stages the students not only learn to plan but also learn tolerance, empathy, attention with the group so that the lesson plans tend to show improvement (Suryani, 2014). The lesson study also provides hope for the development of professionalism based on real conditions in the learning activities directly in the classroom. Teachers or prospective teachers find problems, develop the planning, and implement the learning to solve the problems in learning, especially learning difficulties encountered by students. By knowing the problems of learning directly and then looking for the solutions to solve them by collaboration are an applicable and effective way to improve the professionalism of teachers and prospective teachers. This MLS way is inversely proportional to the increase in professionalism of teachers pursued conventionally by attending seminars, training, or workshops, and conference (Ono \& Ferreira, 2009). This research aims to produce the lesson plan from MLS activities for biology subjects for high school students and to describe the condition of the teaching ability of biology teacher candidate through MLS activity.

\section{Method}

The research design was carried out in a descriptive qualitative manner by observing the implementation of MLS activities were conducted during the even semester of the academic year 2018-2019. The population of this study was 36 students of Biology Education in UNIPMA. The sample was eight students who were chosen purposively of whom created a learning plan of biology materials for the high school level based on curriculum 2013. At the beginning of the lecture, students were given an understanding related to LS that will be conducted with microteaching activities. The students conducted MLS for three months, starting from March to May 2019. Eight students who took the MLS course have never done LS activities at all. Therefore, lecturers provided materials related to the description and implementation of LS in microteaching activities that will be conducted. The introduction of MLS by the lecturer was carried out once at the beginning of the session.

In the implementation of the MLS, the students who conducted LS activities were divided into two groups, each group containing four students. The group was formed to facilitate student discussion in preparing the lesson plan (planning stage). During the implementation of the activities (implementation stage), all students became classical with the division of one student as a model teacher, and other students became observers that were accompanied by a lecturer. The steps of the MLS were conducted according to the procedure developed under Lai \& Lo-Fu (2013) as shown in Figure 1. 


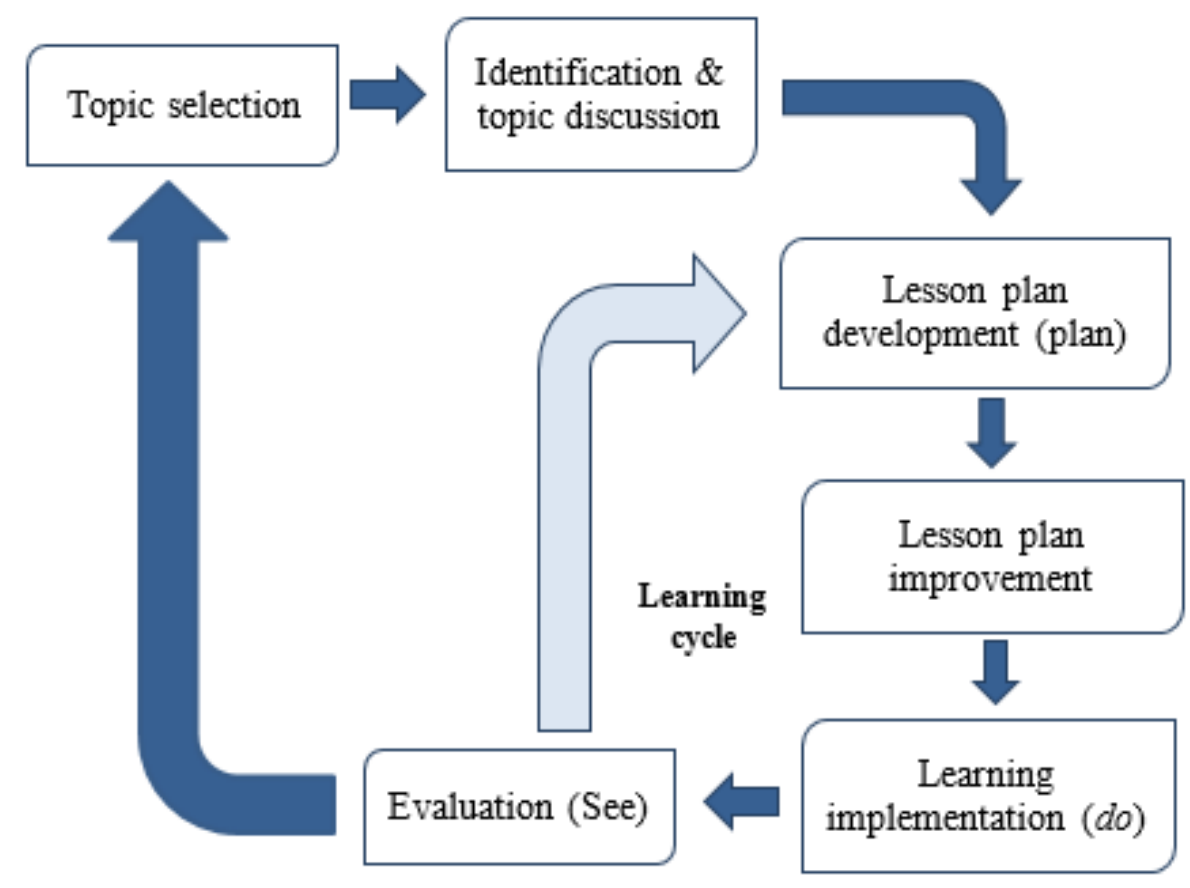

Figure 1. The microteaching-lesson study (MLS) cycle

The data were collected in this study were the ability of the student to arrange and teach pupils after applying MLS. The research instruments were an observation sheet, interview sheet, and micro-teaching result score after conducting MLS. Interview guidance was prepared with three modified reflective questions: 1) student' opinions related to the implementation of MLS, 2) student' perceive of collaborative learning, and 3) student' perspectives and expectations to improve learning quality by implementing LS as a way to do when becoming a teacher in the future. The data were analyzed descriptively and confronted with the information obtained from students' micro-teaching activities after conducting the MLS for three months.

\section{Result and Discussion}

\section{Results}

The implementation of MLS provided a new experience for students in preparing the practical implementation of field practice at school. All students got the opportunity to cooperate actively with the guidance of the lecturers to complete the stages of activities. The activities were started by choosing the topic to be taught, continued by discussing the topics, making learning plans, improving the lesson plans, implementing learning, and finished by evaluating the learning activities.

\section{Selection, Identification, and Discussion of the Learning Topic}

The participants selected the topics for microteaching activities based on the curriculum 2013 for senior high school. During the three lesson study cycles that were implemented, each student carried out the selected independently. The process was followed by the identification of topics as well as discussions with friends to determine the material that will be drafted in the lesson plan. Identification was based on the ability of each student, the allocation of time, the possibility of supporting media, and the learning strategies to apply. The identification and discussion resulted from an agreed topic for the preparation of the lesson plan in Table 1. Table 1 explained that the students had followed the initial agreement to seek and identify the material following their wishes. There was a tendency for students to choose a simple topic (material from class X), but it was understandable because of the concern that they were unable to deliver the material well. The selection of materials 
for the second and third planning had increased in terms of complexity as shown by the already brave students choosing the biology materials from class $\mathrm{XI}$ on the curriculum.

Table 1. Results of topic identification

\begin{tabular}{|c|c|c|c|}
\hline Participants & Topic 1 & Topic 2 & Topic 3 \\
\hline 1 & Biodiversity & Metabolism & Motion system \\
\hline 2 & Virus & Cell & Structure of plants \\
\hline 3 & Fungus & Animalia & $\begin{array}{l}\text { Transport on animals \& } \\
\text { humans }\end{array}$ \\
\hline 4 & Humans excretion System & Bacteria & Growth and development \\
\hline 5 & $\begin{array}{l}\text { Humans Reproduction } \\
\text { System }\end{array}$ & Ecology & $\begin{array}{l}\text { Mutations of genes and } \\
\text { chromosomes }\end{array}$ \\
\hline 6 & $\begin{array}{l}\text { Plant \& animal networks } \\
\text { System }\end{array}$ & $\begin{array}{l}\text { Protista, feature, } \\
\text { and characteristics }\end{array}$ & $\begin{array}{l}\text { Enzymes and cell } \\
\text { metabolism }\end{array}$ \\
\hline 7 & Protista & Cell & $\begin{array}{l}\text { Animal and Human } \\
\text { respiratory system }\end{array}$ \\
\hline 8 & Plantae & Plants Structure & Metabolism \\
\hline
\end{tabular}

The score of lesson plan compilation was based on five components: a) determining the indicator, b) choosing the materials, c) determining the method to be used, d) determining the evaluation technique, e) arranging the instrument of teaching implementation. The complete scores for each component are shown in Figure 2.

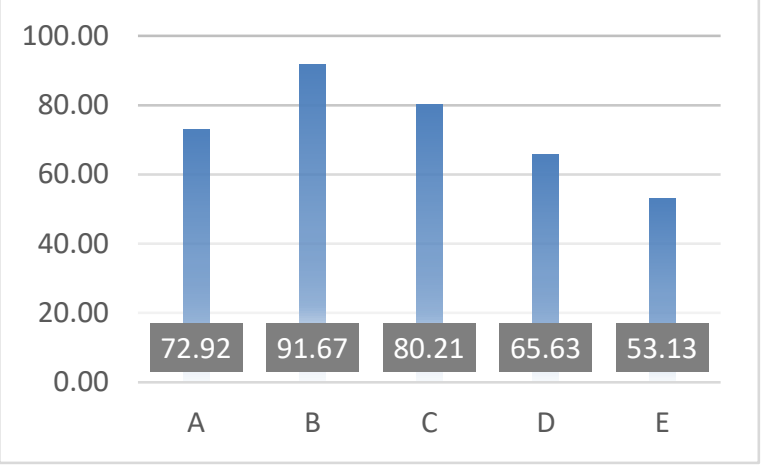

Figure 2. The average scores of the lesson plan based on the component of, a) indicator, b) material, c) method, d) evaluation, e) instrument

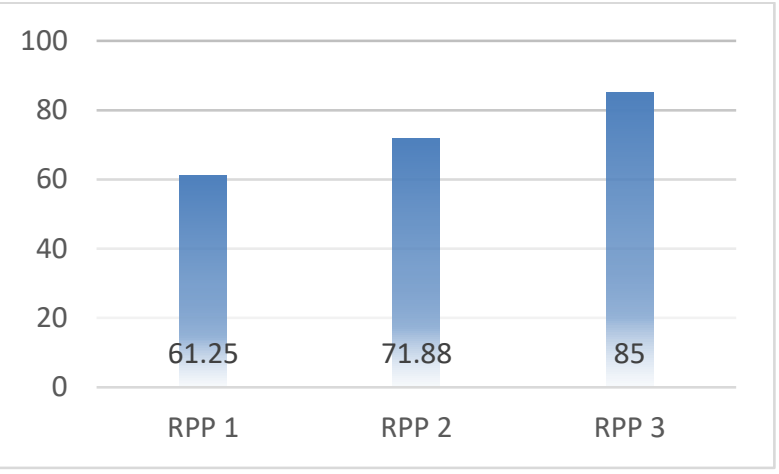

Figure 3. The average score of the lesson plan for three practice sessions by each student

Figure 3 shows that the average scores of the lesson plan created by the students increased from the first, second and third practice sessions. The condition was an illustration that students began to develop better learning plans confidently with the help of friends through the discussion processes. Figure 3 proves that MLS able to be a way for increasing the student ability in compiling the lesson plan.

\section{Support for Discussion on Preparation and Implementation of Learning Plan (Plan)}

The stages of lesson planning were carried out in small groups, consisting of four people in each group. Preparing three lesson plans for each student required three times face-to-face (plan) and then they had to revise independently. Broadly speaking, the results of the prepared planning could be observed in the following classification in Table 2. 
Table 2. Result of student discussion in the preparation of learning planning

\begin{tabular}{|c|c|}
\hline Focus & Suggestion during discussion \\
\hline $\begin{array}{l}\text { Indicator and objective } \\
\text { of the study }\end{array}$ & $\begin{array}{l}\text { - Preparation of indicators to be adjusted to the allocation of } \\
\text { time and target that have been set. } \\
\text { - The learning objectives derived from the indicators need to } \\
\text { consider the elements of audience, behavior, condition, and } \\
\text { degree (ABCD) }\end{array}$ \\
\hline $\begin{array}{l}\text { Apperception (opening } \\
\text { activity) }\end{array}$ & $\begin{array}{l}\text { The questions asked should be based on case studies of daily } \\
\text { activities close to student life. }\end{array}$ \\
\hline Main Activity & $\begin{array}{l}\text { Adjusted to the overall material, strategies used, allocations } \\
\text { required at each stage, appropriate learning media, and } \\
\text { evaluations that need to be tailored to the indicators and } \\
\text { objectives and supporting instruments required. }\end{array}$ \\
\hline $\begin{array}{l}\text { Closing activity \& } \\
\text { Conclusion }\end{array}$ & $\begin{array}{l}\text { Basically, the conclusion of learning activities delivered by } \\
\text { students with teacher guidance. }\end{array}$ \\
\hline Time allocation & Observed and adapted to each stage of the learning plan. \\
\hline Teaching Strategy & $\begin{array}{l}\text { Taking care of class and school conditions, student and teacher } \\
\text { abilities, and time allocation tailored to the material. }\end{array}$ \\
\hline Teaching media & $\begin{array}{l}\text { In each instructional medium that is prepared and will be used } \\
\text { should consider the involvement of students while learning. }\end{array}$ \\
\hline Learning Evaluation & $\begin{array}{l}\text { Taking into account the indicators and learning objectives, } \\
\text { conditions, and ability of prospective teachers when to conduct an } \\
\text { evaluation. No need to force all aspects of cognitive, affective, } \\
\text { and indicator to be assessed or disclosed. }\end{array}$ \\
\hline
\end{tabular}

\section{Implementation of Learning (Do) and Observation}

Based on the result of the learning plan that had been prepared, evaluated, and repaired, then the students implemented microteaching as the arranged schedule. Since there were only eight students who participated in the activity, and one student had to be a model teacher, the lecturer and other students acted as observers. At this stage, the lecturer had the opportunity to provide assessments for students who acted as model teachers, especially in conducting the lesson plans that had been prepared previously. The overall assessment results are presented in Table 3 as follows.

Table 3. The results of the assessment of learning activities

\begin{tabular}{|c|c|c|c|c|}
\hline No & Component & Practice (Do 1) & Practice & Practice \\
\hline 1 & Teaching material & 53,13 & 68,75 & 84,38 \\
\hline 2 & Teaching Strategy & 62,25 & 75,00 & 81,25 \\
\hline 3 & Teaching Media & 53,13 & 65,63 & 84,38 \\
\hline 4 & $\begin{array}{l}\text { The Inclusion of } \\
\text { Students in Teaching } \\
\text { Learning Process }\end{array}$ & 62,50 & 68,75 & 84,38 \\
\hline 5 & Evaluation & 56.25 & 62.50 & 78,13 \\
\hline 6 & $\begin{array}{l}\text { Language \& } \\
\text { Communication }\end{array}$ & 59,38 & 78,13 & 87,50 \\
\hline 7 & Closing & 59,39 & 84,38 & 90,63 \\
\hline & Mean & 55,77 & 71,88 & 84,38 \\
\hline
\end{tabular}

\section{Evaluation (See)}

The reflection or see activity was carried out just after the completion of the do stage. It began with the student who acted as the teacher model to express their experience and followed by the lecturers and other observers to present the findings in the learning process. In the reflection, it was revealed that prospective teacher students indeed had difficulty in 
understanding the material, especially when associated with the real conditions. However, the weaknesses encountered could be discussed so that the student group would find the best solution to solve the learning problem encountered. The process of MLS in the second and third cycles was more organized due to the students understood what to do. The mistakes encountered in the first cycle stage became a valuable experience to do better activities in the second and third cycles. At the end of the third cycle, students were asked to submit all findings as they recorded throughout the cycle and then the lecturer interviewed all students.

\section{Discussion}

\section{Selection, Identification, and Discussion of the Learning Topic}

The lowest average score that obtained from the evaluation and determining instrument to be used in microteaching course, while the other three components show above the average score (see Figure 2). The average scores of lesson plan one to three increased as shown below. The ability of students who conducted microteaching was still low in terms of preparing evaluation and compiling instruments in the learning plan. The detail of the instrument and its components to be measured are the difficulties faced by students when they are correcting or improving the learning plan. Creativity in preparing evaluation and its instruments is an important part for the students in designing the learning plan because the emphasis is not only on cognitive factors, but also to advert on other aspects that really necessary (Aida \& Antoni, 2017; Natalia \& Ditasona, 2019; Murtafiah, Sa'dijah, Chandra, \& Susiswo, 2019).

Figure 3 shows that the average scores of the lesson plan created by the students increased from the first, second and third practice sessions. The condition was an illustration that students began to develop better learning plans confidently with the help of friends through the discussion processes. Figure 3 proves that MLS able to be a way for increasing the student ability in compiling the lesson plan. The important point of MLS implementation are sharing and actively discussion among students so that the details of the learning plan can be scrutinized one by one more carefully (Merdekawati, 2018). On the other hand, it was shown that the good preparation of learning plan made the class more organized and planned so that it provided implementation guidance to achieve learning goals (Contreras et al., 2020).

\section{Support for Discussion on Preparation and Implementation of Learning Plan (Plan)}

Table 2 shows that in the planning activity, many suggestions were received by students who would become a model teacher in microteaching activities. Each member of the group provided ideas, as well as problem-solving related media or evaluation to be implemented. It is no less important that preparing Biology learning plan of laboratory practicum activities is mandatory to be implemented. Suggestions and input during the MLS made the detail of the laboratory practicum implementation significantly improved. Starting from the selection of tools and materials to the designing of implementation procedures in accordance with theme, making the learning plan that is designed has a higher quality. Selection of learning methods by inquiry, project-based learning or problem-based learning with practicum activities (Contreras et al., 2020) are among the things discussed during MLS. During the MLS activities, each student produced three revised learning tools with good and excellent categories.

\section{Implementation of Learning (Do) and Observation}

The results of the assessment of the lesson plan implementation activities from the activities of do 1 , do 2 and do 3 showed a significant improvement in student score. The lowest score in do 1 was the component of the selected subject matter, which includes mastery of the material that was planned to be taught and linked the material to the real conditions and other relevant knowledge. In do 2 and 3, the component of the subject matter indicated a fairly good improvement. The component with the lowest score on do 2 was the evaluation, as well as in do 3, although it increased in those two do. This evidence showed 
that MLS provided successful results to increase the student abilities in practicing implementation of the preparation of lesson plans. The basis of MLS i.e. planning, implementation, and evaluation based on the discussion are the steps to improve student activities (Iksan et al., 2014; Utami et al., 2017). During the micro-teaching practice, students used a variety of means and media based on suggestions arisen when preparing lesson plans (Yigit, 2010), so that practice improvements from time to time have increased.

\section{Evaluation (See)}

The results of in-depth interviews related to the first question were 'what do you feel and think about this MLS' showed that at the beginning of the activity (LS 1) students had difficulty at the beginning of implementation. Four of the eight students who took part in the MLS did not know what to do when the plan was discussed. But after trying to re-read and understand the topic plan belongs to one of their friends, then the discussion began to run well. One by one they tried to look at the existing draft planning to be discussed starting from the form of the lesson plan, indicators, objectives, learning activities with the strategy applied, media, and evaluation needed (Norton, 2018). These conditions indicated the start of positive feelings in each student by starting to look at the draft of the friend's planning. They know and understand that the concept of collegiality with friends was an important thing to do as if they will become a real teacher.

The second interview question was 'to describe the cooperative activities that you do when developing a lesson plan with your group'. All the students who participated in the event felt greatly helped by the collaboration and discussion while developing the lesson plan. The difficulties encountered related to the understanding of learning materials were addressed by collectively looking for relevant and supportive learning resources to be studied. The same thing was done to compile and adjust the evaluation instruments with the specified indicators. It appeared that students became more sensitive and meticulous in terms of adapting the evaluation component to the learning objectives. However, students admitted that time duration was a big issue for them. They needed more time to prepare a neat, complete, and easy to implement learning plan.

The third interview question was 'regarding the expectations and ideals of becoming a teacher in the future, how is a good teacher, and can LS be used as one way to improve teacher professionalism?'. Answering the question all students stated that MLS provided new insights to improve the professionalism of teachers. They knew that being a good teacher needs to pay attention to how students learn about the material given to be able to understand it well. Therefore, enabling students in learning activities became an important key to be considered when preparing lesson plans. But some students also expressed doubts about carrying out LS in the future. These concerns arose concerning the amount of time they need to carry out a cycle of the LS (Chichibu \& Kihara, 2013; Fujii, 2016). On the other hand, they also questioned the readiness and motivation of teachers who would be invited to collaborate in the LS. Observing the answer could be assumed that the students were aware that the teacher had a very complex task. Not only they had to solve the material contained in the curriculum and deliver it well, but also to teach the students to be able and willing to learn independently as their main responsibility.

The results of research related to the implementation of MLS conducted during three months provided supplies to prospective teachers to experience the real conditions that would be faced in PPL activities. The collaborative LS process with friends in the group had a real impact in terms of improving the quality of the learning plan, which would have an impact on the implementation of learning (Asman, 2016; Ceylan \& Ozdilek, 2015). Principles of collaboration in these activities became a real part that was implemented continuously so that cooperation produced sharing knowledge, as well as finding and solving problems together. The same thing was presented in the results of previous study that the application of LS on the students to plan the practicum, carry out and do feedback and reflection could support social sensitivity and generate cognitive interaction among students (Kostas et al., 2014). Other study also stated that the development of professionalism for teachers and 
prospective teachers needs to be implemented in real and LS was able to accommodate these goals (Gutierez, 2015; Murtafiah, 2016; Murtafiah \& Lukitasari, 2019).

The crucial matters of students that related to the ability to understanding biological material when identification, planning, and implementation of learning show improvement. This condition means that MLS provided an opportunity for students to learn the content of the material better. This step was a significant step to reduce the likelihood of low understanding of prospective teachers (Chukwunyere et al., 2017; Shuilleabhain, 2016; Suryani, 2014). The improvement that students made in preparing learning tools covered the entire section including the evaluation component that was still faced difficulty in adjusting and organizing the instrument. The process of discussion and collaboration became an important activity due to the problem of adjustment of evaluation form with the purpose of learning, and the required instrument can be adequately solved.

The report presented in this study did show the positive impact of MLS implementation. However, the difficulty that students faced at the beginning of the MLS activities, as well as the long-time duration required, became a challenge for further study to be resolved. Previous study found more or less the same obstacles associated with the difficulties encountered during the lesson study activities undertaken (Gutierez, 2015; Kanauan \& Inprasitha, 2014). These difficulties include a lack of teacher spirit in implementing lesson study and a misconception of the material and difficulty in arranging the time of its implementation.

Noticing the constraints of this study, it likely that the prospective teacher's students need understanding and sustainable habituation to implement the lesson study in a structured and with a longer time. The diversity of the pupils into their uniqueness could cause some things to be less than optimal in the implementation of lesson study. Nevertheless, overall, it is found that basically, the existence of lesson study could be a bridge to translate teachers' professionalism in the real sense, in a real way through direct involvement of teachers and prospective teachers starting from the beginning of the activity (plan) then carrying out (do) and ending evaluation (see). The lesson study provided a real experience for teacher development. The principle of collaboration became the main force of lesson study to improve the quality of the learning process on an ongoing basis (Doig \& Groves, 2011; Marsigit, 2007, 2016; Myers, 2012; Remesh, 2013; Sumantri et al., 2018; Yoshida, 2008).

\section{Conclusions and Suggestions}

The result of this study pointed to the conclusion that through three cycles of MLS students capable of producing the learning plans with good and excellent levels, improving of teaching ability, and classroom management. The preparation of lesson plans by means of discussion and collaboration makes it easy for students even though they require more time and a high willingness to do so. The stages in MLS that were applied comprehensively help students in preparing of the teaching practices in schools. Preparations that were carried out carefully by paying attention to suggestions and inputs regarding of learning content was the strength of this microteaching implementation. In some components, such as evaluation and its instruments required, show weaknesses, but these can be properly resolved as the students spend more time of discussion in the MLS stages. The application of MLS showed effective results in preparing of learning implementation carried out by prospective teacher' students.

\section{References}

Aida, W., \& Antoni, R. (2017). Basic Components of Micro Teaching Skill At Third Year Student FKIP Universitas Pasir Pengaraian. Journal of English Education, 3(2), 100112. https://journal.upp.ac.id/index.php/JEE/article/view/512.

Asman, H. (2016). The Capacity of Microteaching Lesson Study in Promoting Teaching Practice and Pedagogical Development. Jurnal Pendidikan Bahasa, 5(2), 198-213. 
https://journal.ikippgriptk.ac.id/index.php/bahasa/article/view/325.

Ceylan, S., \& Ozdilek, Z. (2015). Improving a Sample Lesson Plan for Secondary Science Courses within the STEM Education. Procedia - Social and Behavioral Sciences, 177(July 2014), 223-228. https://doi.org/10.1016/j.sbspro.2015.02.395.

Chichibu, T., \& Kihara, T. (2013). How Japanese schools build a professional learning community by lesson study. International Journal for Lesson and Learning Studies, 2(1), 12-25. https://doi.org/10.1108/20468251311290105.

Chukwunyere, B. B., Chigozie, R., \& Chibuike, R. (2017). The Impact of Microteaching in Developing Teaching Skills among Pre-Service Teachers in Alvan Ikoku College of Education Owerri, Nigeria. African Research Review, 11(2), 237-1994. https://doi.org/10.4314/afrrev.v11i2.18.

Contreras, K., Arredondo, C., Díaz, C., Inostroza, M. J., \& Strickland, B. (2020). Examining differences between pre- and in-service teachers' cognition when lesson planning. System, 91, 102240. https://doi.org/10.1016/j.system.2020.102240.

Damalie, S. N. (2018). Student-teachers' experiences of microteaching on an economics methods course. African Research Review, 12(2), 101. https://doi.org/10.4314/afrrev.v12i2.10.

Doig, B., \& Groves, S. (2011). Japanese Lesson Study: Teacher Professional Development through Communities of Inquiry. Mathematics Teacher Education and Development, 13(1), 77-93. https://eric.ed.gov/?id=EJ960950.

Fujii, T. (2016). Designing and adapting tasks in lesson planning: a critical process of Lesson Study. ZDM - Mathematics Education, 48(4), 411-423. https://doi.org/10.1007/s11858-016-0770-3.

Gellert, U. (2008). Routines and collective orientations in mathematics teachers' professional development. Educational Studies in Mathematics, 67(2), 93-110. https://doi.org/10.1007/s10649-007-9089-x.

Ghanaguru, S., Nair, P., \& Yong, C. (2013). Teacher trainers' beliefs in microteaching and lesson planning in a teacher training institution. English Teacher, 42(2), 216-228.

Gutierez, S. B. (2015). Collaborative professional learning through lesson study: Identifying the challenges of inquiry-based teaching. In Issues in Educational Research (Vol. 25, Issue 2).

Handayani, S. (2018). Microteaching Practices based on Multiple Intelligence: A Research and Development of Students ' Handbook for English Language. The 2nd International Conference on Technology, Education, and Social Science 2018, 268275.

Hasan, R., Lukitasari, M., Utami, S., \& Anizar, A. (2019). The activeness, critical, and creative thinking skills of students in the Lesson Study-based inquiry and cooperative learning. Jurnal Pendidikan Biologi Indonesia, 5(1), 77-84.

Hj Iksan, Z., Aishah Mohd Nor, S. N., Nordiyana Mahmud, S., \& Zakaria, E. (2014). Applying the principle of "Lesson study" in teaching science. Asian Social Science, 10(4), 108113. https://doi.org/10.5539/ass.v10n4p108.

Iksan, Z. H., Zakaria, E., \& Daud, M. Y. (2014). Model of lesson study approach during micro teaching. International Education Studies, 7(13), 253-260. https://doi.org/10.5539/ies.v7n13p253.

Kanauan, W., \& Inprasitha, N. (2014). Collaboration between Inservice Teachers and Student Intern in Thai Lesson Study. Procedia - Social and Behavioral Sciences, 116, 28-32. https://doi.org/10.1016/j.sbspro.2014.01.163.

Kostas, K., Galini, R., \& Maria, M. (2014). The Practicum in Pre - Service Teachers' Education in Greece: The Case of Lesson Study. https://doi.org/10.1016/j.sbspro.2014.09.325.

Lai, M. Y., \& Lo-Fu, Y. W. P. (2013). Incorporating learning study in a teacher education program in Hong Kong: a case study. International Journal for Lesson and Learning Studies, 2(1), 72-89. https://doi.org/10.1108/20468251311290141.

Ledger, S., \& Fischetti, J. (2020). Micro-teaching 2.0: Technology as the classroom. Australasian Journal of Educational Technology, 36(1), 37-54. 
https://doi.org/10.14742/ajet.4561.

Marble, S. (2007). Inquiring into Teaching: Lesson Study in Elementary Science Methods. Journal of Science Teacher Education, 18(6), 935-953. https://doi.org/10.1007/s10972-007-9071-6.

Marsigit. (2007). Mathematics Teachers Professional Development through Lesson Study. Eurasia Journal of Mathematics, Science \& Technology Education, 3(2), 141-144.

Marsigit. (2016). Lesson Study Among the Move of Educational Reformation in Indonesia. Proceeding Of 3rd International Conference On Research, Implementation And Education Of Mathematics And Science, 16-17.

Merdekawati, K. (2018). The implementation of lesson study to improve the teaching skills of chemistry teacher candidates. Journal of Physics: Conference Series, 1116(4). https://doi.org/10.1088/1742-6596/1116/4/042022.

Murata, A. (2011). Conceptual Overview of Lesson Study. In Lesson Study Research and Practice in Mathematics Education (pp. 1-12).

Murtafiah, W. (2016). Peningkatan Kemampuan Mengembangkan Perangkat Pembelajaran Mahasiswa Calon Guru Matematika Pada Matakuliah Microteaching Melalui Lesson Study. Jurnal Edukasi, 2(1), 1-14.

Murtafiah, W., \& Lukitasari, M. (2019). Developing Pedagogical Content Knowledge of Mathematics Pre-Service Teacher through Microteaching Lesson Study. Jurnal Pendidikan Matematika, 13(2), 201-218.

Murtafiah, W., Sa'dijah, C., Chandra, T. D., \& Susiswo, S. (2019). Decision making of the Winner of the National Student Creativity Program in Designing ICT-based Learning Media. TEM Journal, 8(3), 1039-1045. https://doi.org/10.18421/TEM83-49.

Myers, J. (2012). Lesson Study as a Means for Facilitating Preservice Teacher Reflectivity. International Journal for the Scholarship of Teaching and Learning, 6(1). https://doi.org/10.20429/ijsotl.2012.060115.

Natalia, S., \& Ditasona, C. (2019). Analysis of the difficulties in determining the right evaluation instrument in teaching practice student teachers of mathematics education study program. International Journal of Innovation, Creativity and Change, 5(3), 1003-1033.

Norton, S. (2018). Middle School Pre- Service Teachers ' Mathematics Content Knowledge and Mathematical Pedagogy Content Knowledge: Assessing and Relating. Proceedings of the 41st Annual Conference of the Mathematics Education Research Group of Australasia, July, 599-606.

Nugraheni, F. S. A. (2019). Learning difficulties in microteaching class: A case study. AIP Conference Proceedings, 2194 (December). https://doi.org/10.1063/1.5139803.

Okobia, E. O., Augustine, O. E., \& Osagie, R. . . (2013). An Analysis of the Perceived Challenges Faced by Student-Teachers during Teaching Practice Exercise. Undefined, 4, 7-11.

Ono, Y., \& Ferreira, J. G. (2009). (PDF) A case study of continuing teacher professional development through lesson study in South Africa. South African Journal of Education, 30, 59-74.

Remesh, A. (2013). Microteaching, an efficient technique for learning effective teaching. In Journal of Research in Medical Sciences (Vol. 18, Issue 2, pp. 158-163).

Saun, S. (2015). Problems Done by The Microteaching Students in Teaching The Grammar For A Communicative Purpose. Poceedings of ISELT-3, 411-418.

Shuilleabhain, A. N. (2016). Developing Mathematics Teachers 'Pedagogical Content Knowledge in Lesson Study: Case Study Findings. International Journal of Lesson and Learning Study, 5(3), 212-226.

Sumantri, M. S., Prayuningtyas, A. W., Rachmadtullah, R., \& Magdalena, I. (2018). The Roles of Teacher-Training Programs and Student Teachers' Self-Regulation in Developing Competence in Teaching Science. Advanced Science Letters, 24(10), 7077-7081. https://doi.org/10.1166/asl.2018.12412.

Suryani, F. B. (2014). Developing a Model of Microteaching Lesson Study for English Student Teachers. Proceedings of World Association of Lesson Studies, 6-10. 
Utami, I. W. P., Mashuri, \& Nafiáh, U. (2017). A Model of Microteaching Lesson Study Implementation in the Prospective History Teacher Education. Journal of Education and Practice, 7(27), 10-14.

Yang, L. (2017). The Problems of and Solutions to Micro-teaching for English Pedagogical Students. 40 (Icelaic 2016), 147-152. https://doi.org/10.2991/icelaic-16.2017.36.

Yigit, N. (2010). Developing presentation skills of student teachers through micro-teaching method. Energy Education Science and Technology Part B: Social and Educational Studies, 2(2), 55-74.

Yoshida, M. (2008). Exploring Ideas for a Mathematics Teacher Educator's Contribution to Lesson Study (pp. 85-106). Brill | Sense. https://doi.org/10.1163/9789087905460_006. 